\title{
Assessment of Quality Management Practices of Building Construction Firms in Uganda: A Case of Kamwenge District
}

\author{
Muhwezi Lawrence*, Baguma Andrew, Mubiru Joel \\ Department of Civil and Building Engineering, Kyambogo University, Kampala, Uganda \\ Email address: \\ lmuhwezi@hotmail.com (M. Lawrence), Bagumaandrew90@gmail.com (B. Andrew), mubirudalt@yahoo.com (M. Joel) \\ *Corresponding author
}

\section{To cite this article:}

Muhwezi Lawrence, Baguma Andrew, Mubiru Joel. Assessment of Quality Management Practices of Building Construction Firms in Uganda: A Case of Kamwenge District. Journal of Civil, Construction and Environmental Engineering. Vol. 6, No. 2, 2021, pp. 77-86.

doi: $10.11648 /$ j.jccee.20210602.17

Received: February 15, 2021; Accepted: March 26, 2021; Published: April 20, 2021

\begin{abstract}
Quality management in the construction industry includes quality control, quality planning and quality assurance to improve the quality of buildings. However, there have been challenges related to cost variations, timeliness and delays in maintenance which affect quality management of buildings. The study assessed quality management practices of building construction firms in Uganda with the purpose of developing a framework that can be used by construction firms to improve on the quality of buildings. In this study, descriptive design was employed in which both qualitative and quantitative data were collected from a sample size of 54 respondents purposively selected from employees of construction firms and Kamwenge local government using a survey questionnaire and documentary reviews. Data were analyzed using descriptive and multivariate analysis in SPSS version 25. The contribution of each of the factors on the quality of construction firms was determined by use of Relative Importance Index (RII) and the ranking of these attributes in terms of their criticality as perceived by the respondents. The findings indicated that procurement systems, third party certification and on site supervision greatly influenced the cost, timeliness and delivery of buildings hence affecting the quality management practices. The developed framework shall be used to engage stakeholders in the phases of the construction projects mainly buildings to improve on cost estimation and timely completion hence improving on quality management of buildings and service delivery.
\end{abstract}

Keywords: Quality Management, Quality Planning, Quality Control, Construction Firms

\section{Introduction}

Construction industry has been widely criticized for its low quality of delivery of construction projects [1]. Construction firms need to adopt quality management in order to solve quality problems in order to meet the demands of the clients [2]. Total quality management is defined as a management viewpoint that encompasses all functions of an entity like human resources, operations and marketing in order to focus on meeting customer needs and firm's objectives [3].

Globally, building construction sector is considered to be a basic sector on which the development of a country depends [4]. Quality of global firms in building projects is driven by practices adopted [5]. It is asserted that the majority of the construction companies in all over the world face a lot of many challenges and problems such as workmanship defects, delay and cost overrun in complementing their construction projects for the past three decades [6].

Total quality Management culture has contributed to increased productivity of firms around the world [7]. Global international, regional and local firms always strive to gain competitive edge in building projects based on TQM initiatives that are customer centric in nature. In Africa, [8] pointed out that the collapse of buildings in Africa has been attributed to weak foundations, substandard construction materials, poor material mixing by construction workers, excessive load on strength of buildings and poor testing of 
building strength. Many construction industries have criticized especially in terms of productivity and quality system because implementing managers mainly focus on the cost and time instead of quality for construction projects [9].

Collapsed buildings are a growing problem where many buildings in the region's major cities are under construction or renovation [10]. Research indicates that Kenya has probably suffered the most building collapses in the last decade due to lack of quality and poor construction materials [11]. In one of those instances, it was revealed that although the developer was served with a stoppage order due to violation of construction regulation and huge cracks that had developed in the said building, work continued and hence the collapse [12].

In Uganda, it is estimated that building construction employs $1.3 \%$ of the total registered employees with ideal of quality output [13]. The construction industry contributed $12 \%$ of the GDP by 2005 [14]. Despite this contribution, there have been reported cases of irregularity in the quality of buildings whereby for example a storied building collapsed in the city suburb of Kansanga and the causes were poor materials and inexperienced engineers. This, therefore, prompted the Government to shift the contracts to design-build with the notion that the contractor will do more testing to improve on the quality of designs and save construction costs [15].

\subsection{Statement of the Problem}

Building construction firms in Uganda implement ISO 9001 Quality Management System and obtain consequent approvals, rewards and certificates. The standard is based on a number of quality management principles including a strong customer focus, the motivation and implication of top management, the process approach and continual improvement and using US ISO 9001:2015 helps to ensure that customers get consistent good quality products and services, which in turn brings many business benefits. The design and implementation of building construction's quality management system is influenced by varying prices of inputs for instance, there was highest 25.8 percent increase in average prices of inputs in the overall construction sector registered in 2011, followed by an increase of 11.4 percent in 2009 and the lowest increases in average prices for the whole sector was 2.2 percent which was registered in 2013 [1]. Despite the standard set by $1 \mathrm{SO} 9001$, the quality of buildings have continued to deteriorate in Kamwenge district whereby there has been a high death rate because of collapsed buildings during rainy seasons and earth quakes, they have experienced cost and time over run. The cause of the breakdown might be caused by un experienced personnel using poor materials to maintain the quality of building projects by many building firms and it is against this background that this study sought to assess the quality management practices of building construction firms in Uganda particularly Kamwenge District.

\subsection{Objectives of the Study}

The main objective of the study was to assess the quality management practices of building construction firms in Uganda and was guided by the following specific objectives:

i) To determine the current quality management practices in building construction firms in Uganda;

ii) To determine the extent to which quality management is practiced in building construction firms in Uganda.

iii) To establish the challenges in implementation of quality management practices in building construction firms in Uganda.

iv) To develop a framework for effective quality management practices in building construction firms in Uganda.

\section{Literature Review}

\subsection{Stakeholder Theory}

The study was guided by stakeholder theory that was propounded by [16]. According to [17], the "maximizing shareholder value" view is put forward as a "scientific" theory that is modeled and verified appropriately by ideologists called "economists." On the other hand, a study by [18] argued that stakeholder ship involved a theory of organizational management and ethics which was distinct because it addressed morals and values as explicit central features of organizational management. He also pointed out that management for stakeholders involved attention to more than simply maximizing shareholder wealth.

\subsection{Quality Management Systems in Construction Projects}

Quality system is defined as "the organizational structure, responsibilities, procedures, processes, and resources for implementing quality management" [19]. On the hand, quality management system refers to the set of quality activities involved in producing a product, process, or service, and encompasses prevention and appraisal [20]. It is a management discipline concerned with preventing problems from occurring by creating the attitudes and controls that make prevention possible [21]. Quality activities include: determination of the quality policy, objectives and responsibilities and implementing them through quality planning, quality control, quality assurance and quality improvement, within the quality system [19].

\subsection{Factors Affecting Project Time Delay and Cost Overruns}

\subsubsection{Quality Planning and Quality Assurance}

Quality planning is defined as a set of activities whose purpose is to define quality system policies, objectives, and requirements, and to explain how these policies will be applied, how these objectives will be achieved, and how these requirements will be met [21]. Quality assurance is defined as a set of activities whose purpose is to demonstrate that an entity meets all quality requirements. Quality 
assurance activities are carried out in order to inspire the confidence of both customers and managers, confidence that all quality requirements are being met. It is noted that quality requirements should be clear and verifiable so that all parties in the project can understand them for conformance [22]. Quality assurance emphasizes defect prevention, unlike quality control that focuses on defect detection once the item is produced or constructed. According to [22], it was further established that quality assurance concentrates on the production or construction management methods and procedural approaches to ensure that quality is built into the production system.

\subsubsection{Stakeholder Framework and Building Construction}

Stakeholder involvement in building construction involves determining how to plan, developing the scope statement, selecting the planning team, identifying deliverables and creating the work breakdown structure, identifying the activities needed to complete those deliverables and networking the activities in their logical sequence, estimating the resource requirements for the activities. It also involves estimating time and cost for activities, developing the schedule, developing the budget, risk planning and gaining formal approval to begin work in order to construct output with quality specification, time and cost [23].

Stakeholders can affect an organization's functioning, goals, development and even survival [24]. Successful engagement of stakeholders involves actively giving and getting their support and working together to devise, plan and develop new construction designs [25]. Senior leaders in construction projects can adopt stakeholder engagement as an opportunity to influence other organizations and create alignment to structures and processes to support the vision and mission of timeliness, quality, durability and minimizing costs [26].

\section{Methodology}

Research design as the overall plan or strategy for conducting research [27]. It is a master plan specifying the methods and procedure for collecting, analyzing and interpreting the data in order to get the desirable information. The study adopted descriptive survey design citing [28] that descriptive survey design is easy to manage and administer. The design is preferred because it will give a broad understanding that leads to a justifiable means of investigating the relationship between variables in the study. The study sample that was randomly selected constituted 10 local government officials in engineering and procurement departments and 50 employees of construction firms prequalified with Kamwenge District because they were believed to have enough knowledge for the study. Data were collected using a self-administered questionnaire, interviews, desk survey and a document review guide. The questionnaire was selected as the main data collection tool because it is cheap to administer and covers a wide geographical area; it provides a hard copy that can be filed for reference purposes.
The questionnaire was equally used because the information had to be collected from a large sample in a short period of time. The questionnaire was pretested for content validity and a content validity index (CVI) value of 0.75 was obtained. These CVI values exceeded the 0.7 threshold implying a reliable questionnaire as suggested by [29]. Interview guides were also administered to the top district management for indepth data collection.

\subsection{Data Collection}

The study used multiple sources of data because of the added benefits (such as the validity of the data gathered) associated with multiple sources fieldwork (primary data collection) and desk study (secondary data collection). The approach for collecting data in this study was divided into two main parts desk survey and field survey.

\subsection{Data Analysis}

The filled questionnaires were collected, checked for accuracy, consistency and completeness before leaving the field. Raw data was entered into Statistical Package for Social Scientists (SPSS-version 25) and analyzed statistically. The contribution of each of the factors to overall delays was examined and the ranking of the attributes in terms of their criticality as perceived by the respondents was done by use of Relative Importance Index (RII) which was computed, the five-point likert scale ranged from 1 to 5 that was adopted and transformed to relative importance indices (RII) for each factor using equation (1).

$$
\mathrm{RII}=\frac{\sum W}{A \times N}(0 \leq \mathrm{RII} \leq 1)
$$

Where;

$\mathrm{W}=$ weighting given to each factor by the respondents (ranging from 1 to 5 ),

$A=$ highest weight ( 5 in this case)

$\mathrm{N}=$ total number of respondents $(\mathrm{N}=54)$

Variables with RII $<0.599$ were deemed to be insignificant in quality management, variables were further considered to be critical or not where they were RII $\geq 0.73$. Therefore, in this study, RII $\geq 0.73$ was considered to be critical, $0.599<$ $\mathrm{RII}<0.73$ was considered to be significant, RII $<0.599$ were deemed to be insignificant in this study.

\subsection{Frame Work Development}

A framework was developed to show how different stakeholders are involved at different stages i.e. initiation stage, planning stage, implementation stage evaluation and handover stages to enhance the quality of buildings in Kamwenge district.

\section{Results and Analysis}

The results about demographic factors are presented in Table 1. 
Table 1. Demographic factors.

\begin{tabular}{llll}
\hline Category & Variables & Frequency & Percent \\
\hline \multirow{2}{*}{ Sex } & Male & 33 & 61.1 \\
& Female & 21 & 38.9 \\
Age & $18-30$ & 8 & 14.8 \\
& $31-40$ & 24 & 44.4 \\
& $41-50$ & 16 & 29.6 \\
Level of education & above 50 years & 6 & 11.1 \\
& Certificate \& Below & 12 & 22.2 \\
& Diploma & 42.6 & \\
Profession & Degree & 23 & 25.9 \\
& Masters & 14 & 9.3 \\
& Q/S & 5 & 20.3 \\
& Land surveyor & 11 & 20.3 \\
Position & Engineer & 11 & 55.6 \\
& Architect & 30 & 3.7 \\
& Manson & 2 & 46.3 \\
& Carpenter & 25 & 22.2 \\
& Electrician & 12 & 9.3 \\
\end{tabular}

Source: Primary data (2019)

The results in Table 1 show that the male respondents were $33(61.1 \%)$ and female $21(38.9 \%)$ which implies that majority were male who participated in the study. The ages of respondents were grouped and 18-30 were 8 (14.8\%), 31-40 were $24(44.4 \%), 41-50$ were $16(29.6 \%)$ and above 50 years were $6(11.1 \%)$ which signifies that majority were aged 31 40. About the level of education, respondents with certificate and below were $12(22.2 \%)$, diploma holders were 23 (42.6\%), degree holders were $14(25.9 \%)$ and masters respondents were $5(9.3 \%)$ which shows that majority of the respondents were degree holders. The professional of respondents were $\mathrm{Q} / \mathrm{S}$, land surveyor, engineer and architect with $11(20.3 \%), 11(20.3 \%), 30(55.6 \%)$ and $3(2.7 \%)$ respectively. The positions of respondents were $25(46.3 \%)$ for mansions, $12(22.2 \%)$ for carpenters, 5 (9.3\%) for electrician, $4(7.4 \%)$ for plumbers and $8(14.8 \%)$ for still fixers, the majority of the respondents who participated in the study were mansions.

\subsection{Quality Management Practices of Construction Buildings}

The results in Table 2 indicate that proper procurement systems were ranked $1^{\text {st }}$ with the highest RII of 0.84 . This shows that proper procurement systems influence quality planning of building construction to a larger extent. This is in agreement with [30] who indicated that there was a trend for firms to prefer using competitive procurement systems to promote transparency, economy and efficiency and limit favoritism. Furthermore, Table 2 shows that firms always train their employees on quality was ranked $2^{\text {nd }}$ with relative importance index of 0.82 which shows that training influences quality planning of building construction to moderate extent. This is in agreement with [31] who suggested that in order to facilitate the acquisition of skills and expertise for employees on quality of construction projects, training must become a mainstream function and an integral part of any firm's strategic direction. Job site quality plan was ranked $3^{\text {rd }}$ with RII of 0.79 . This implies that site plans contribute moderately relatively less to quality management of construction projects. The factor that resources are mobilized in time and realistic plans are drafted were assessed with RII of 0.65 and 0.58 ranked $4^{\text {th }}$ and $5^{\text {th }}$ respectively insignificantly contribute to quality management practices.

Table 2. Quality Planning.

\begin{tabular}{llll}
\hline S/No & Statement & R11 & \\
\hline 1 & Proper procurement systems are adhered to & 0.84 & $1^{\text {st }}$ \\
2 & Firms always train theiremployees on quality & $2^{\text {nd }}$ & 0.82 \\
3 & There is job site quality plan & 0.79 & $3^{\text {rd }}$ \\
4 & Resources are mobilized in time & $4^{\text {th }}$ & 0.65 \\
5 & Realistic plans are drafted & $5^{\text {th }}$ & 0.58 \\
\hline
\end{tabular}

RII $\geq 0.73=$ Critical, $0.599<$ RII $<0.73=$ Significant, $\mathrm{RII}<0.599=$ =Insignificant

\subsection{Quality Control}

According to [32] quality control is critically important to a successful construction project and should be adhered to throughout a project from conception and design to construction and installation. He further asserted that inspection during construction will prevent costly repairs after the project is completed, the inspector, engineer, 
contractor, funding agency, permit agency, and system personnel must work together to inspect, document, and correct deficiencies. Results in Table 3 indicate that project managers always conduct onsite-supervision and there is compliance to standards of relevant agencies with RII of 0.93 and 0.89 respectively, this shows supervision and compliance to standards are critical in quality control of construction building projects. Team work among employees $(\mathrm{RII}=0.72)$, client adhering to a work plan ( $\mathrm{RII}=0.62)$ were significant in quality control of buildings projects since $0.599<\mathrm{RII}<0.73$. This finding agrees with [32] who asserted that quality control is critically important to a successful construction project and should be adhered to throughout a project from conception and design to construction and installation. It is asserted that inspection during construction will prevent costly repairs after the project is completed; the inspector, engineer, contractor, funding agency, permit agency, and system personnel must work together to inspect, document, and correct deficiencies [32]. However, [33] agreed that quality control is evaluating whether construction projects adhere to specific standards.

Table 3. Quality Control.

\begin{tabular}{llll}
\hline S/No & Statement & R11 & Rank \\
\hline 1 & Project managers always conduct onsite-supervision & 0.93 & $1^{\text {st }}$ \\
2 & There is compliance to standards of relevant agencies & 0.89 & $2^{\text {nd }}$ \\
3 & There is team work among employees & 0.72 & $3^{\text {rd }}$ \\
4 & Client's work plan that are adhered to & 0.62 & $4^{\text {th }}$ \\
\hline
\end{tabular}

RII $\geq 0.73=$ critical, $0.599<$ RII $<0.73=$ Significant, $\mathrm{RII}<0.599=$ Insignificant

\subsection{Quality Assurance Practices}

Results in Table 4 indicate that third party certification and adequate allocation of resource with RII of 0.92 and 0.78 respectively were ranked highly thus critical in quality management of construction building. This shows that quality assurance in construction firms is greatly affected by third party certification and budget allocation. The research also revealed there is moderate effect on the quality management practices of construction building projects were since implementers paying attention to needs of clients was ranked $3^{\text {rd }}$ with RII of 0.72 , employees are motivated in every firm $(\mathrm{RII}=0.67)$ ranked $4^{\text {th }}$ and quality appraisals in the firm $(\mathrm{RII}=0.62)$ ranked $5^{\text {th }}$. This shows that paying attention to needs of clients, motivation of employees in firm and quality appraisal are very significant since $0.599<$ RII $<0.73$.

Table 4. Quality Assurance Practices.

\begin{tabular}{llll}
\hline S/No & Quality assurance practice & R11 & Rank \\
\hline 1 & Third party certification & 0.92 & $1^{\text {st }}$ \\
2 & Adequate budget is always allocated for activities & 0.78 & $2^{\text {nd }}$ \\
3 & Implementers always pay attention to needs of clients & 0.72 & $3^{\text {rd }}$ \\
4 & Employees are motivated in every firm & 0.67 & $4^{\text {th }}$ \\
5 & There is quality appraisals in the firm & 0.62 & $5^{\text {th }}$ \\
6 & There are changes in administration & 0.52 & $6^{\text {th }}$ \\
7 & Customers are always satisfied about quality & 0.46 & $7^{\text {th }}$ \\
\hline
\end{tabular}

$\mathrm{RII} \geq 0.73=$ Critical, $0.599<\mathrm{RII}<0.73=$ Significant, $\mathrm{RII}<0.599=$ =Insignificant

Other quality assurance factors such as changes in administration $(\mathrm{RII}=0.52)$ and customer's satisfaction about quality $(\mathrm{RII}=0.46)$ are insignificant since RII $<0.599$. These findings are in agreement with [34]) who pointed out that quality assurance is easily compromised and frequently lost since construction firms rely heavily upon the individual contributions to implementation from each designer, contractor, supplier and sub-contractor.

\subsection{Extent to Which Quality Management Is Practiced in Building Projects}

The second objective of the study sought to establish the extent to which quality management is practiced in building construction projects in Kamwenge district. The research undertaken on building construction projects in Kamwenge district revealed in Table 5 that that testing materials before use with highest $\mathrm{RII}=0.95$ was ranked top. This research revealed that skilled personnel $(\mathrm{RII}=0.94)$, regular meetings of staff $(\mathrm{RII}=0.91)$, meeting general construction standards $(\mathrm{RII}=0.89)$, clearly defining goals and objectives $(\mathrm{RII}=0.82)$ and employing experienced worker $(\mathrm{RII}=0.78)$ are critical since RII $\geq 0.73$. This implies that they have high effect on the quality management practices of building projects in Kamwenge district.

Table 5 further shows that well-defined roles and responsibilities of workers $(\mathrm{RII}=0.71)$ ranked $7^{\text {th }}$, training and educating of team members on quality $(\mathrm{RII}=0.66)$ ranked $8^{\text {th }}$ and sub-contractor's involvement in the quality process $(\mathrm{RII}=0.62)$ ranked $9^{\text {th }}$ had moderate effect on the quality management of projects and were significant since $0.599<$ $\mathrm{RII}<0.73$. Table 5 still indicate that building of good storage facilities $(\mathrm{RII}=0.51)$ ranked $10^{\text {th }}$ has less effect on quality 
management practices of projects since RII $<0.599$.

Table 5. Extent to Which Quality Management is practiced.

\begin{tabular}{|c|c|c|c|}
\hline No & Statement & RII & Rank \\
\hline 1 & Testing materials before use & 0.95 & $1^{\text {st }}$ \\
\hline 2 & Having a skilled work force & 0.94 & $2^{\text {nd }}$ \\
\hline 3 & Regular meetings of staff & 0.91 & $3^{\text {rd }}$ \\
\hline 4 & Meeting general construction standards & 0.89 & $4^{\text {th }}$ \\
\hline 5 & Clearly defining goals and objectives & 0.82 & $5^{\text {th }}$ \\
\hline 6 & Employing experienced worker & 0.78 & $6^{\text {th }}$ \\
\hline 7 & Well-defined roles and responsibilities of workers & 0.71 & $7^{\text {th }}$ \\
\hline 8 & Training and educating of team members on quality & 0.66 & $8^{\text {th }}$ \\
\hline 9 & Subcontractors involvement in the quality process & 0.62 & $9^{\text {th }}$ \\
\hline 10 & Building good storage facilities & 0.51 & $10^{\text {th }}$ \\
\hline
\end{tabular}

Key: $\mathrm{RII} \geq 0.73=$ critical, $0.599<\mathrm{RII}<0.73=$ significant, $\mathrm{RII}<0.599=$ =nsignificant

\subsection{Challenges of Implementation of Quality Management in Building Projects}

The third objective was to assess the challenges of implementation of quality management in construction projects in Kamwenge district. The research undertaken established that poor designs was the most critical challenge on the facing the quality management of construction projects with relative importance index of 0.94 and was ranked top challenge of construction projects as indicated in Table 6.

\subsubsection{Quality Planning Challenges}

From the summary of results in Table 6, it can be observed that the key challenges that critically affect the quality in building construction projects in Uganda were; Poor designs $(\mathrm{RII}=0.94)$; lack of proper equipment available for use $(\mathrm{RII}=0.93)$, lack of enough knowledge of the project $(\mathrm{RII}=0.91)$ and poor scheduling of projects $(\mathrm{RII}=0.84)$ respectively. Table 6 further shows that setting unrealistic deadlines $(\mathrm{RII}=0.72)$ and poor health standards at the site (RII=0.63) significantly affect the quality planning of projects since $0.599<\mathrm{RII}<0.73$. The research, however, revealed that three (3) factors had minimal effect of quality planning and they include; bureaucracy of clients $(\mathrm{RII}=0.52)$, poor estimates $(\mathrm{RII}=0.46)$ and clients setting of unrealistic deadlines $(\mathrm{RII}=0.42)$.

Table 6. Quality Planning Challenges.

\begin{tabular}{llll}
\hline S/N & Quality planning challenges & RII & Rank \\
\hline 1 & Poor designs & 0.94 & $1^{\text {st }}$ \\
2 & Lack of proper equipment available for use & 0.93 & $2^{\text {nd }}$ \\
3 & Lack of enough knowledge of the project & 0.91 & $3^{\text {rd }}$ \\
4 & Poor scheduling of projects & 0.84 & $4^{\text {th }}$ \\
5 & Setting unrealistic deadlines & 0.72 & $5^{\text {th }}$ \\
6 & Poor sanitation and health standards at the site & 0.63 & $6^{\text {th }}$ \\
7 & Bureaucracy of clients & 0.52 & $7^{\text {th }}$ \\
8 & Poor estimates & 0.46 & $8^{\text {th }}$ \\
9 & Clients setting of unrealistic deadlines & 0.42 & $9^{\text {th }}$ \\
\hline
\end{tabular}

RII $\geq 0.73=$ critical; $0.599<$ RII $<0.73=$ Significant; RII $<$ $0.599=$ Insignificant

These findings are in line with [34] who revealed that the main causes of material and equipment procurement delay in quality management were organizational weaknesses, suppliers' defaults, governmental regulations, and transportation delays. However, [20] contends that construction project fails due to time and cost overruns resulting from; poor field investigation, under-estimates, lack of experience, inadequate project analysis, and poor investment decisions. Poor planning for implementation entails inadequacies in time plan, resource plan, equipment plan, coordination, organization, cost planning and improper pre/post contract actions. Furthermore, findings are in agreement with [35] who asserted that that inefficient and ineffective working delays, low resources productivity, change in scope, affects the planning of buildings. It is further argued that unclear objectives, unworkable schedules, failure to identify critical items, lack of understanding of operating procedures, and ignorance of appropriate planning techniques are all a manifestation of poor planning and poor management [36].

\subsubsection{Quality Control Challenges}

Table 7. Quality Control Challenges.

\begin{tabular}{llll}
\hline S/No & Quality control challenges & RII & Rank \\
\hline 1 & Lack of management's commitment & 0.96 & $1^{\text {st }}$ \\
2 & Lack of enough funds & 0.92 & $2^{\text {nd }}$ \\
3 & It is very expensive in testing materials & 0.87 & $3^{\text {rd }}$ \\
4 & Poor testing procedures & 0.86 & $4^{\text {th }}$ \\
5 & Delay in delivering materials & 0.72 & $5^{\text {th }}$ \\
6 & Stakeholder's influence & 0.68 & $6^{\text {th }}$ \\
7 & Poor conduct of review meeting & 0.59 & $7^{\text {th }}$ \\
8 & No good stores at the site & 0.56 & $8^{\text {th }}$ \\
9 & No site safety measures & 0.45 & $9^{\text {th }}$ \\
\hline \multirow{2}{*}{$\geq \quad$ RII $<0.73=$ critical, $0.599=$ Significant, RII } &
\end{tabular}

Results in Table 7 indicate that lack of management's commitment was a critical challenge affecting quality of building projects with RII of 0.96 and was ranked top challenge critically affecting the quality control of construction buildings. Furthermore, from Table 7, the challenges that critically significantly affect the quality control in construction projects are; lack of enough funds $(\mathrm{RII}=0.92)$, very expensive in testing materials $(\mathrm{RII}=0.87)$, poor testing procedures $(\mathrm{RII}=0.86)$, delay in delivering 
materials $(\mathrm{RII}=0.72)$ and stakeholder's influence $(\mathrm{RII}=0.68)$ since RII $>0.599$. These challenges are in agreement with [37] who revealed that contract managers often face challenge of quality management due to unclear project scope, and unrealistic timeline and budgets in controlling the quality of construction buildings.

\subsubsection{Quality Assurance Challenges}

Results from Table 8 indicate that lack of skilled personnel for implementation ( $\mathrm{RII}=0.97$ ) was a critical challenge affecting quality assurance of construction projects in Kamwenge district. Challenges such as; lack of a quality assurance team to lead the process $(\mathrm{RII}=0.92)$, high labourturnover in the firm $(\mathrm{RII}=0.93)$, poor security in the area $(\mathrm{RII}=0.86)$, no enough experience of workers $(\mathrm{RII}=0.82)$, poor decision making from clients $(\mathrm{RII}=0.85)$ and no timely completion of each phase $(\mathrm{RII}=0.62)$ respectively greatly affects the quality assurance of construction projects as presented in Table 8 since RII $>0.599$. In a related study it was found out that organizational segmentation, reluctant managers, industrial relation and short term mission are some of the challenges of TQM implementation [38]. It was also pointed out that organizational culture, lack of management commitment, lack of teamwork, poorly thought out plans, focus on short term profit, poor measurement techniques, lack of education and training programs, employee fear of losing their jobs are some of the barriers of TQM implementation [38].

Table 8. Quality Assurance Challenges

\begin{tabular}{llll}
\hline S/No & Quality Assurance challenges & Rank & \\
\hline 1 & Lack of skilled personnel's for implementation & 0.97 \\
2 & Lack of a quality assurance team to lead the process & $1^{\text {st }}$ & \\
3 & High labour turnover in the firm & $2^{\text {nd }}$ & 0.92 \\
4 & Poor security in the area & $3^{\text {rd }}$ & 0.93 \\
5 & No enough experience of workers & $4^{\text {th }}$ & 0.86 \\
6 & Poor decision making from clients & $5^{\text {th }}$ & 0.82 \\
7 & No timely completion of each phase & $6^{\text {th }}$ & 0.85 \\
& & $7^{\text {th }}$ & 0.62 \\
\hline
\end{tabular}

RII $\geq 0.73=$ critical, $0.599<$ RII $<0.73=$ Significant, $\mathrm{RII}<0.599=$ Insignificant

\subsection{Filling the Gap in Construction Projects}

The study established that despite the identified pitfalls in procurement planning processes, the respondents had faith in the correction of the anomalies and loopholes identified in the planning process and made suggestions which have been incorporated in the Framework developed by this study to close the gaps quality management practices in Kamwenge district. According to Figure 1, building construction should under the following phases to maintain quality:

\subsubsection{Initiation Phase}

This is the first phase of the construction project and in this phase, the project objective or need is identified. A feasibility study is conducted to investigate whether each option addresses the project objective and a final recommended solution is determined. Once the recommended solution is approved, a construction project is initiated to deliver the approved solution and a project manager (District engineer) is given an approval by CAO. The major deliverables and the participating work groups are identified, and the project team begins to take shape. Approval is then sought by the project manager to move into the detailed planning phase. Stakeholders that always participate at this phase are $\mathrm{CAO}$, district engineers, district planner and community represented by political leaders.

\subsubsection{Planning Phase}

The planning phase, is where the building project solution is developed in as much detail as possible and the steps necessary to meet the building project's objective are planned. In this step, the District planner, district engineer, CAO, Political leaders identifies all of the work to be done. The building project's tasks and resource requirements are identified, along with the strategy for producing them. A project plan is created outlining the activities, tasks, dependencies, amount needed and timeframes. District engineer, procurement officers, planners and Chief finance officer coordinates the preparation of a project budget by providing cost estimates for the labour, equipment, and materials costs. Finally, a quality plan is documented, quality targets provided, assurance, and control measures, along with an acceptance plan, listing the criteria to be met to gain customer acceptance.

\subsubsection{Implementation Stage}

During the third phase, the building project plan is put into motion and the work of the project is performed. Progress is continuously monitored and appropriate adjustments are made and recorded as variances from the original plan. District engineer spends most of the time in this step. During project implementation, contractors are carrying out the tasks, and progress information is being reported to the Chief Administrative officer. District engineer uses this information to maintain control over the direction of the project by comparing the progress reports with the project plan to measure the performance of the project activities and take corrective action as required of him. Throughout this step, project funder and other key stakeholders should be kept informed of the project's progress according to the agreed-on frequency and format of communication. Progress reports should always emphasize the anticipated end point in terms of cost, schedule, and quality of deliverables. Each project deliverable produced should be reviewed for quality and measured against the acceptance criteria. 


\subsubsection{Closing Phase}

During the final closure, or completion phase, the emphasis is on having over the final deliverables to the community, handing over project documentation to the business, terminating supplier contracts, releasing project resources, and commissioning of the project.

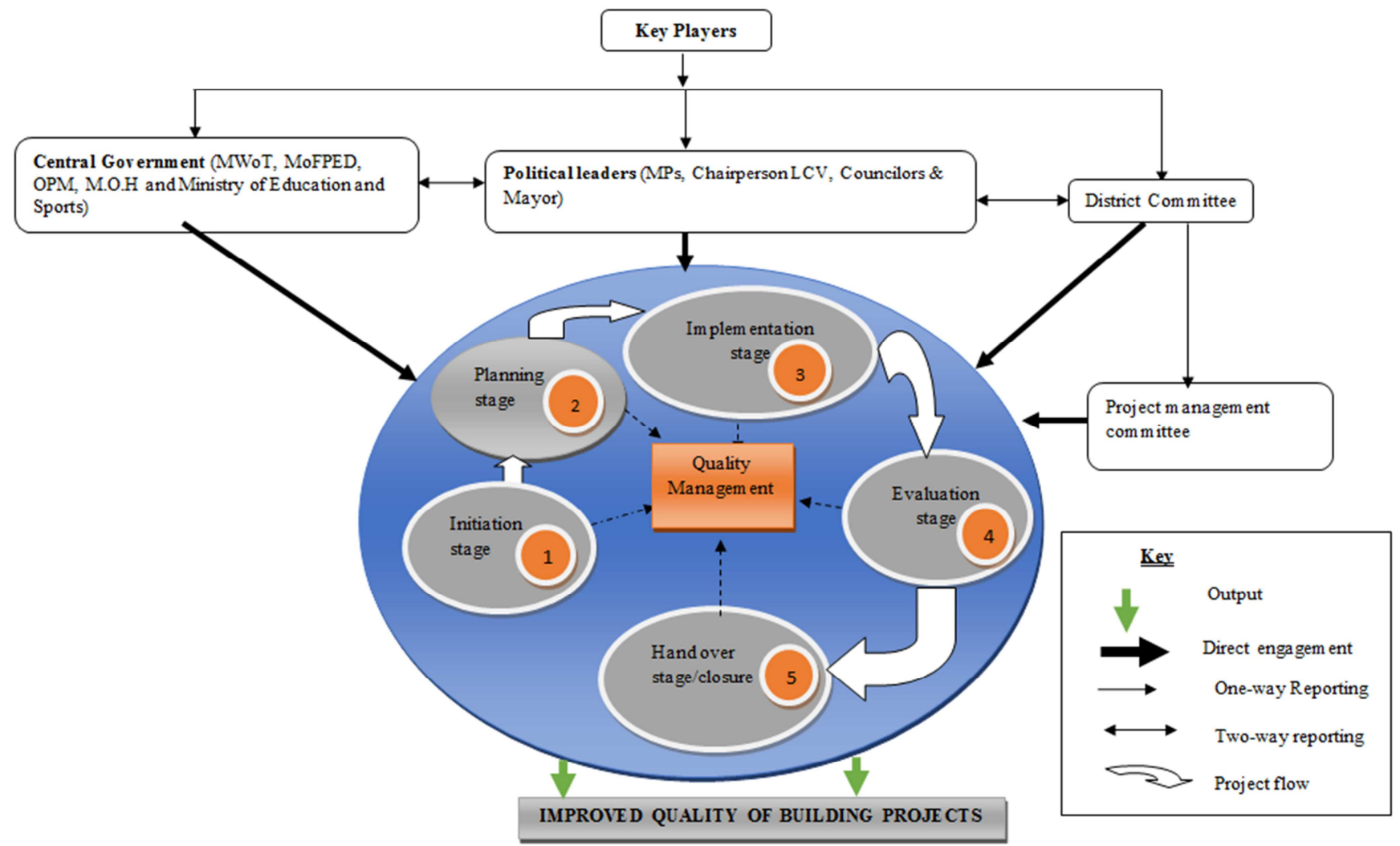

Figure 1. Developed Framework for Improving Quality Management of Buildings Projects

\subsection{Role of each Stakeholder}

\subsubsection{Central Government}

Quality management process involves two ministries that include MoWT and MoFPED, MoFPED is charged with allocating funds to DLGs through CAO and District engineer. MoWT is responsible for supervision, monitoring and evaluation of performance of construction projects, making follow ups, supervision and audits of contracted projects. The Office of the Prime Minister is charged with monitoring and evaluation.

\subsubsection{Chief Administrative Officer}

This is the chief accounting officer for the whole project. $\mathrm{He}$ is charged with authorizing funds that are used in every activity of building projects.

\subsubsection{District Engineer}

This charged with supervising the whole process of construction projects from initiation stage to handover. He is also charged with maintaining the project to reduce defects in the project.

\subsection{Closing the Gaps in the Quality Management Process}

\subsubsection{Training of Staff}

In the Framework (Figure 1), the researcher suggests that the only one way of closing the gaps in the quality management practices is by training staff on short courses. The training opportunities are provided for the purposes of enhancing the concerned intervention groups with skills and capacity to implement and maintain quality as indicated by doted black arrows. This could take inform of refresher quality training that could be organized at the district or outside the district. This could help to maintaining quality in all stages of the building construction projects.

\subsubsection{Revising the Budgetary Allocations}

Budget allocations are done by central government and in order to maintain quality of buildings. In closing the gaps in quality management, budget for building projects should be increased to because Kamwenge district has been facing a challenge of poor allocation of resources. In other words, more pressing issues like quality management should be given first priority with big budget. From the framework, this is indicated by purple arrow from the ministry to DLGs represented by $\mathrm{CAO}$.

\subsubsection{Providing Logistics to Relevant Stakeholders}

This is what enables the relevant stakeholders to perform their duties in building construction projects for example supervision vehicles, material testing kits for quality assurance, protective gears, equipment like concrete mixers, excavators and many more, therefore, the central government/funder should provide the necessary logistical to 
Kamwenge Local Government to support the force account mechanism.

\section{Conclusions and Recommendation}

The study concluded that the top most challenge affecting quality management of construction buildings was poor designs in construction projects in Uganda. The study recommended that proper procurement methods should be adhered to, there should also be third party certification, material testing should be done before actual implementation of works and there should be a quality assurance team to ensure quality of building construction projects in Uganda.

\section{References}

[1] Hoonakker P, Loushine T, Carayon P, Kallman J, Kapp A, Smith M. J., (2015)."The effect of safety initiatives on safety performance: A longitudinal study. Applied Ergonomics", 36 (4): 461-469.

[2] Ashokkumar, D., (2014). "Study of Quality Management in Construction Industry", International Journal of Innovative Research in Science Engineering and Technology, 3 (1), 36-43.

[3] Hashmi, K. (2010). "Introduction and Implementation of Total Quality", Retrieved from; https://www.isixsigma.com/methodol/total-qualitymanagementtqm/introductionand-implementationtotalqualitymanagement-tqm/.

[4] Wasiu, A. B., Aliu, A. \& Modupe, A., (2012). "An Assessment of Implementation of Quality Culture in Construction", Department of Building, University of Lagos.

[5] Bell, M., \& Omachonu, V., (2011). "Quality system implementation process for business success", International Journal of Quality and Reliability Management, 28 (7), 723734.

[6] Neyestani, B., \& Juanzon, J. B. P., (2016a.). Developing an Appropriate Performance Measurement Framework for Total Quality Management (TQM) in Construction and Other Industries, IRA-International Journal of Technology \& Engineering, 5 (2), 32-44.

[7] Kiprotich. A. M; Njuguna. R and Kilika. J., (2018). "Total Quality Management Practices and Operational Performance of Kenya Revenue Authority", International Journal of Contemporary Aspects in Strategic Management (IJCASM), 2 (1), 91-105, ISSN 2616-6976.

[8] Fernandez, R. H. F., (2014). "Strategies to reduce the risk of building collapse in developing countries" Doctoral thesis, Department of Engineering and Public Policy, Carnegie Mellon University, Pittsburgh, PA.

[9] Ali, A and Rahmat, H., (2010). "The performance measurement of construction projects managed by ISOcertified contractors in Malaysia", Journal of Retail \& Leisure Property, 9 (1), 25-35.

[10] Muhumuza, R., (2013). "Building collapses in Uganda, killing at least four", Associated Press, Retrieved from. https://www.sandiegouniontribunecom/sdu -buildingcollapses-in-uganda-killing-at-least-4-2013jul22-story.html.
[11] Wachira, M., (2015). Another city building collapses Daily Nation, Retrieved from https://www.nation.co.ke/counties/nairobi/ZimmermanBuilding-Collapse/1954174-2789530kfdf3t/index.html.

[12] Alinaitwe. H. M. (2008). An assessment of clients' performance in having an efficient building process in Uganda, Journal of Civil Engineering and Management, 14 (2), 73-78.

[13] Uganda Ministry of Finance, Planning and Economic development (2018); Background to the budget fiscal years 2018/2019. Industrialization for Job creation and prosperity.

[14] Mutikanga H, Sharma S and Vairavamoorthy. K., (2013). "Methods and Tools for Managing Losses in Water Distribution Systems" Journal of Water Resources Planning $\begin{array}{llll}\text { and } & \text { Management } 139 & \text { (2): 166-174. DOI: }\end{array}$ 10.1061/(ASCE)WR.1943-5452.0000245.

[15] Uganda Bureau of Statistics Statistical Abstract, (2015). Statistics house, Kampala, www.ubos.org.

[16] Freeman, R. E.(1984). "Strategic management: A stakeholder approach", Boston: Pitman; Pitman series in business and public policy.

[17] McCloskey, D. N., (1998). "The Rhetoric of Economics" (2nd ed.), The University of Wisconsin Press, Madison.

[18] Phillips. R., (2003). "Stakeholder Theory and Organizational Ethics", Berrett-Koehler, Publishers, Inc. ISBN: 1 57675-2682.

[19] Battikha, M., (2000). "Integrating construction productivity and quality management", Proceedings of the28th Annual Conference, CSCE, London, Ontario, 150-77.

[20] Burati, J. L., Farrington, J. J. and Ledbetter, W. B., (1992). "Causes of Quality Deviations in Design and Construction" Journal of Construction Engineering and Management, 118 (1), 34-49.

[21] Harris, F \& McCaffer, R. (2001). "ModernConstruction Management", 5thed. London: Blackwell Publishing.

[22] Khan S, Cao QY, Zheng M, (2008). "Health risks of heavy metals in contaminated soils and food crops irrigated with wastewater in Beijing, China", Environ Pollution; 152 (3): 686-92. doi: 10.1016/j.envpol.2007.06.056.

[23] Harold, K., (2010). "Project Management Best Practices", Canada: International Institute of learning Willey and Sons.

[24] Chinyio, E \& Olomolaiye, P., (2009). "Construction Stakeholder Management", 1st ed.; Wiley Blackwell: London, UK, ISBN: 978-1-405-18098-6.

[25] Pearson, U \& Olander, S., (2004). "Methods to Estimate Stakeholder Views of Sustainability for Construction Projects" In Proceedings of the 21th Conference on Passive and Low Energy Architecture, Eindhoven, The Netherlands, 19-22, Press.

[26] Quinn, L. \& Dalton. M., (2009). "Leading for sustainability: implementing the tasks of leadership", Corp. Govern, 9 (1), 21-38.

[27] Bryman, A., \& Bell, E., (2003). "Business Research Methods", Oxford; New York: Oxford University Press.

[28] Mugenda, O. M., \& Mugenda, A. G., (2003). "Research methods: Qualitative and Quantitative Approaches", Nairobi: Acts Press. 
[29] Katebire, D. A., (2007). "Social research methodology: An introduction". Makerere University Printery: Makerere University, Kampala.

[30] Lynch, J., (2014). "Public procurement and contract administration: A brief introduction Procurement Class". Room Series Book 1.

[31] Garavan, T. \& O'Brien, F., (2001). An investigation into the relationship between safety climate and safety behaviors in Irish organizations. Irish Journal of Management; 22 (1), 141170 .

[32] Liu Y, (2013).’Development of Quality Management Systems: How Have Disruptive Technological Innovations in Quality Management Affected Organizations?" DO: 10.12776/qip.v17i1.154.

[33] Adenuga, A. H. \& Fakayode, S. B. \& Adewole, R. A., (2013). "Marketing Efficiency and Determinants of Marketable Surplus in Vegetable Production in Kwara State, Nigeria," Fourth International Conference, September 22-25, 2013, Hammamet, Tunisia 160533, African Association of Agricultural Economists (AAAE).
[34] Mohan. R. M \& Dinesh, K. A., (2002). "Material and equipment procurement delays in highway projects in Nepal" International Journal of Project Management 20 (8) 627-632. 10.1016/S0263-7863(02)00027-3.

[35] Chitkara, K. K., (2009). "Construction Project Management: Planning, Scheduling and Controlling", Tata McGraw Hill Education Private Limited, New Delhi.

[36] Angeles, R. and Nath, R., (2007). "Business-to-business eprocurement: success factors and challenges to implementation", Supply Chain Management: 12 (2), 104-115. https://doi.org/10.1108/13598540710737299.

[37] Wilkinson, A. M., (1991). "The scientist's handbook for writing papers and dissertations", Englewood Cliffs, NJ: Prentice Hall. ISBN-13: 9780139694110.

[38] Ismail. J. L (2012). "An evaluation of the implementation of Total Quality Management (TQM) within the construction sector in the United Kingdom and Jordan". Doctoral thesis, University of Huddersfield. 